\title{
Second-Degree Burn
}

National Cancer Institute

\section{Source}

National Cancer Institute. Second-Degree Burn. NCI Thesaurus. Code C76131.

An injury that includes the entire epidermis and upper layers of the dermis due to a

chemical, friction, radiation or thermal exposure. The affected area appears as moist red or white skin that does not blanch. Often it is painful with the presence of blisters. 